\title{
Surface application of limestone and calcium-magnesium silicate in a tropical no-tillage system
}

\author{
G.S. A. Castro ${ }^{1 *}$, C.A. C. Crusciol' ${ }^{2}$, C.H. M. da Costa ${ }^{3}$, J. Ferrari Neto ${ }^{2}$, M.A.C. Mancuso ${ }^{2}$
}

${ }^{1}$ Embrapa Monitoramento por Satélite (EMBRAPA), Av. Soldado Passarinho, $n^{\circ} 303,13070-115$, Campinas, São Paulo State, Brazil. ${ }^{2}$ São Paulo State University (UNESP), College of Agricultural Science, Dep. of Crop Science, Lageado Experimental Farm, Rua José Barbosa de Barros, $n^{\circ}$ 1780, 18610-307, Botucatu, São Paulo, Brazil, ${ }^{3}$ Federal University of Goias (UFG), Regional Jatai, Special Academic Unit of Agricultural Sciences, BR 364, km 195, n³800,75801-615, Jatai, Goias, Brazil.

*Corresponding author: gustavo.castro@embrapa.br

\begin{abstract}
Although lime is currently the most commonly applied material for soil acidity correction in Brazil, calciummagnesium silicate application may efficiently replace this source due to its higher solubility and silicon supply, which is beneficial for plant development. This study aimed to evaluate the efficiency of surface liming and silicate application on soil chemical attributes as well as soybean and maize nutrition, yield components, and grain yield. The experiment was conducted in a Rhodic Hapludox in Botucatu-SP, Brazil. The randomized complete block design contained 16 replications. Treatments consisted of two materials for soil acidity correction (dolomitic lime, calcium/magnesium silicate), applied on October 2006 to raise base saturation up to $70 \%$, and a control, with no acidity correction. Soybean and maize were sown in 2006/2007 and 2007/2008, respectively. After 18 months $\mathrm{Ca}-\mathrm{Mg}$ silicate corrected soil acidity up to $0.60 \mathrm{~m}$, and increased exchangeable base levels up to $0.40 \mathrm{~m}$. Silicate increased silicon concentrations in plant tissues in both crops as well as phosphorus in soybean. The application of both sources increased calcium and magnesium concentrations as well as yield components and yield grains of soybean and maize. Soil acidity correction improved the efficiency of fertilizers applied for grain production.
\end{abstract}

Keywords: acid soils, Brazilian 'Cerrado', liming, annual crops 


\section{Introduction}

Many tropical soils in biomes similar to the Brazilian Cerrado and the African Savannah have limited yield potentials because of soil acidity and other fertility issues. Soil acidification is a natural process that can be minimized by using appropriate agricultural management techniques, such as the application of lime. In a soil-plant system, soil acidity interacts with physical, chemical and biological factors, and can result in erosion, low water-holding capacity, low exchangeable base retention capacities, and $\mathrm{Al}$ and Mn toxicity (Fageria and Baligar, 2008).

Lime is the most commonly used material for correcting acidity in Brazil due to its price and its ability to increase the efficiency of any fertilizers applied for grain production. Nevertheless, lime is not very soluble and its dissociated components show limited mobility. Consequently, the effects of liming are usually restricted to the soil's surface layers (Caires et al., 2006; Soratto and Crusciol, 2008; Castro et al., 2011). Other materials may be applied for acidity correction as long as the source is composed of neutralizing components or active ingredients, such as calcium and/or magnesium oxides, hydroxides, carbonates, and silicates.

Some of the materials studied for their soil acidity amendment are sugar foam (Navarro et al., 2009), mussel shells (Álvarez et al., 2012), pulp mill sludge (Gallardo et al., 2016) and calcium and magnesium silicates (Crusciol et al., 2016), and all have given good results. The calcium and magnesium silicates use is increasing, particularly, due the similar composition to carbonates. Therefore, these materials could potentially replace lime and have additional advantages. Silicate application is recommended based on the same methods used for lime requirements (Korndörfer et al., 2004).
According to Alcarde and Rodella (2003), calcium silicate is 6.78 times more water-soluble than calcium carbonate $\left(\mathrm{CaSiO}_{3}=0.095 \mathrm{~g} \mathrm{dm}^{-3} ; \mathrm{CaCO}_{3}=\right.$ $0.014 \mathrm{~g} \mathrm{dm}^{-3}$ ); therefore, this material is a good option for surface application, such as application in no tillage systems (Castro et al., 2011; Crusciol et al., 2016), and for supplying Si. In grasses, Si is scattered over leaf cell walls, stems, and the epidermis of grain coats as a double layer of silica-cuticle and silica-cellulose (Ma and Yamaji, 2006). The deposition of Si may decrease water losses through evapotranspiration and increase tolerance to pests, diseases (Haynes, 2014), heavy metals, toxic aluminum (Prabagar et al., 2010), and lodging. In addition, plants become more erect and show improved photosynthetic efficiency in the presence of $\mathrm{Si}$ (Pulz et al., 2008; Dorneles et al., 2016).

Studies have been published regarding the soil acidity amendment sources as an alternative to liming. Navarro et al. (2009), working with sugar foam during a 25-year experiment, observed an increase on soil $\mathrm{pH}, \mathrm{N}, \mathrm{P}$ and $\mathrm{Ca}$, as well as in the organic matter in a red soil in Spain. The authors stated that the use could replace the traditional liming sources.

Mussel shells are also another alternative, with similar effects on soil $\mathrm{pH}$ and $\mathrm{Al}^{3+}$ neutralization (Álvarez et al. 2012). However, there are researches on grain production with slag application, and indicates that this source can be more efficient than other materials (aqueous lime and sewage sludge) for correcting deeper soil layers due to its higher solubility (Corrêa et al., 2007).

Furthermore, supplying Si may improve yield stability by enhancing the tolerance of crops to water stress because almost all of the soybean and maizeproducing regions in Brazil are not irrigated and 
are liable to drought, particularly in the Brazilian Cerrado region. Most studies emphasize the effects of liming materials for correcting soil acidity, which subsequently affect soil fertility, crop nutrition, and crop yield (Corrêa et al., 2008; Soratto and Crusciol, 2008). Because climatic conditions, soil fertility, and agricultural management influence all yield components, it is important to evaluate these factors individually, especially regarding their relationships with $\mathrm{Si}$.

The purpose of this study was to evaluate the effects of surface liming and $\mathrm{Ca}-\mathrm{Mg}$ silicate application on soil chemical attributes, plant nutrition, yield components, and yields of soybean and maize in a pre-established no tillage system in a dry-winter region.

\section{Materials and Methods}

This experiment was conducted in Botucatu in the State of São Paulo, Brazil (geographical coordinates are $48^{\circ}$ $23^{\prime} \mathrm{W}, 22^{\circ} 51^{\prime} \mathrm{S}$ and 765 meters above sea level) during two consecutive growing seasons (2006-2007 and 2007-2008). The soil in this area is classified as a deep acid clayey Rhodic Hapludox. According to the Köeppen's classification system, the climate in this region is Cwa, which corresponds to a tropical altitude with a dry winter and a hot wet summer. During the experiment, the rainfall and monthly average temperatures were registered (Figure 1). Before initiating the experiment, the chemical characteristics of the soil (in the top $20 \mathrm{~cm}$ ) were determined according to the methods of Raij et al. (2001). The following results were obtained: an organic matter content of $18.25 \mathrm{~g} \mathrm{dm}^{-3}, \mathrm{pH}\left(\mathrm{CaCl}_{2}\right)$ of 4.2, P (resin) concentration of $3.62 \mathrm{mg} \mathrm{dm}^{-3}$, exchangeable $\mathrm{K}, \mathrm{Ca}$, and $\mathrm{Mg}$ values of $0.76,11.62$, and $5.75 \mathrm{mmol}_{\mathrm{c}} \mathrm{dm}^{-3}$, respectively, CEC of 74.98 $\mathrm{mmol}_{\mathrm{c}} \mathrm{dm}^{-3}$, and a base saturation of $24.2 \%$. The soil $\mathrm{pH}$ was determined in a $0.01 \mathrm{~mol} \mathrm{~L}^{-1} \mathrm{CaCl}_{2}$ suspension (1:2.5 soil/solution). The organic matter content of the soil was determined using the calorimetric method. Total acidity in $\mathrm{pH} 7.0(\mathrm{H}+$ Al) was estimated by SMP-buffer solution method (van Raij, Andrade, Cantarella and Quaggio, 2001).

Exchangeable Al was extracted with neutral $1 \mathrm{~mol}$ $\mathrm{L}^{-1} \mathrm{KCl}$ at a $1: 10$ soil/solution ratio and determined by titration with $0.025 \mathrm{~mol} \mathrm{~L}^{-1} \mathrm{NaOH}$ solution. Phosphorus and exchangeable $\mathrm{Ca}, \mathrm{Mg}$ and $\mathrm{K}$ were extracted with ion-exchange resin and $\mathrm{P}$ was determined by colorimetry and $\mathrm{Ca}, \mathrm{Mg}$ and $\mathrm{K}$ by atomic absorption spectrophotometry. Using the exchangeable bases and total acidity at $\mathrm{pH} 7.0(\mathrm{H}+$ $\mathrm{Al}$ ) results, base saturation (1) and CEC (2) values were calculated using the following equation (van Raij et al., 2001):

Base Saturation (\%) $=\left(\mathrm{Ca}_{\mathrm{ex}}+\mathrm{Mg}_{\mathrm{ex}}+\mathrm{K}_{\mathrm{ex}}\right) 100 / \mathrm{CEC}$ (1)

Where $\mathrm{Ca}_{\mathrm{ex}}, \mathrm{Mg}_{\mathrm{ex}}$, and $\mathrm{K}_{\mathrm{ex}}$ are basic exchangeable cations and CEC is the total cation exchange capacity, calculated as Equation (2).

CEC $\left(\mathrm{mmol}_{\mathrm{c}} \mathrm{dm}^{-3}\right)=\mathrm{Ca}_{\mathrm{ex}}+\mathrm{Mg}_{\mathrm{ex}}+\mathrm{K}_{\mathrm{ex}}+$ total acidity in $\mathrm{pH} 7.0(\mathrm{H}+\mathrm{Al})$ 


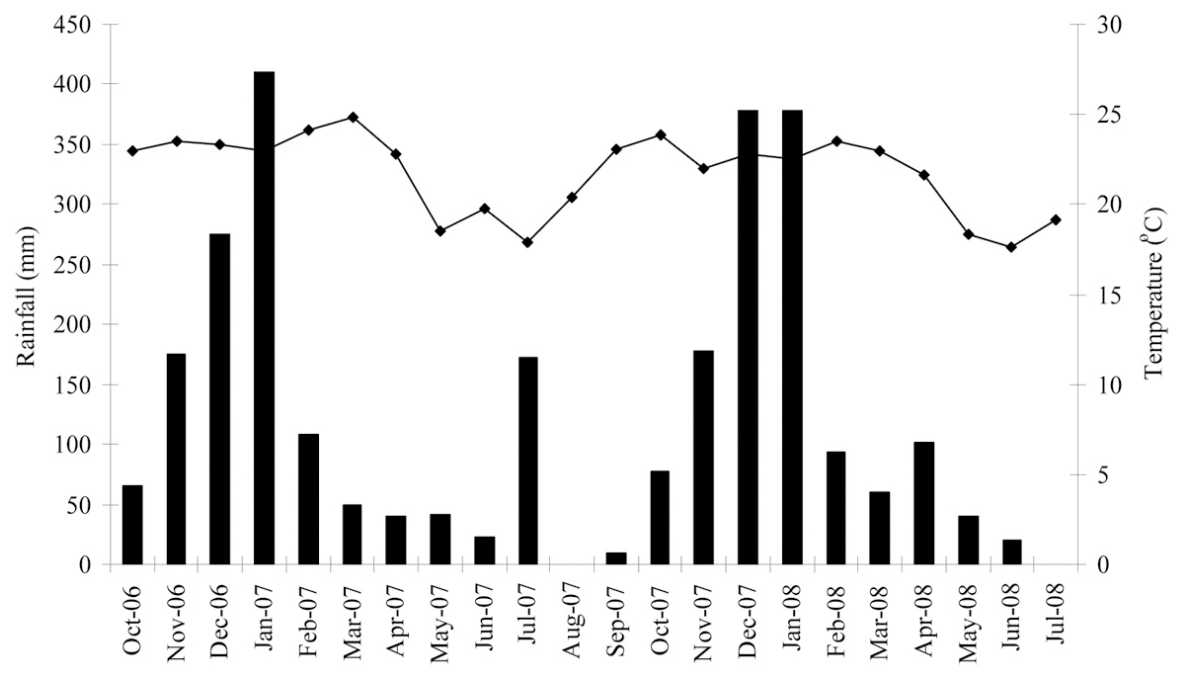

Figure 1.Temperature and rainfall during the study period, from October 2006 to July 2008.

The experiment was conducted using a completely randomized block design with sixteen replications. The treatments $(5.4 \times 10-\mathrm{m}$ plots $)$ consisted of two sources for soil acidity correction (dolomitic lime: Effective Calcium Carbonate $(\mathrm{ECC})=90 \%, \mathrm{CaO}=36 \%$ and $\mathrm{MgO}=12 \%$; calcium/magnesium silicate: $\mathrm{ECC}=80 \%$, $\mathrm{CaO}=34 \%, \mathrm{MgO}=10 \%$ and $\mathrm{SiO}_{2}=22 \%$ ) and a control with no soil correction.

The application rates were calculated to increase the soil base saturation by up to $70 \%$. In October 2006, 3.8 $\mathrm{Mg} \mathrm{ha}^{-1}$ of dolomitic lime and 4.1 $\mathrm{Mg} \mathrm{ha}^{-1}$ of calcium/ magnesium silicate were applied on the soil surface.

Soybean (Glycine max (L.) Merril) cultivar Embrapa 48 was sown on November $29^{\text {th }} 2006$ using a row spacing of $0.45 \mathrm{~m}$ and a sowing rate of 22 seeds $\mathrm{m}^{-1}$. This intermediate maturation-cycled genotype is highly demanding for soil fertility. Seeds were treated with fungicide (vitavax + thiram $-50+50 \mathrm{~g}$ of the active ingredient every $100 \mathrm{~kg}$ of seeds) and an inoculant (Bradyrhizobium japonicum). Base fertilization consisted of $250 \mathrm{~kg} \mathrm{ha}^{-1}$ of a 04-20-20 NPK formula, which was based on the soil chemical analysis results and the recommendations for soybean crops (Raij et al., 1996).

The full flowering stage of the soybean plants occurred 45 days after seedling emergence. At full flowering, 10 plants were sampled and evaluated for their shoot dry matter production. Additionally, the $3^{\text {rd }}$ leaf (with the petiole) was sampled from 30 plants in each plot according to the methods of Raij et al. (1996) for macronutrient and silicon concentration analysis. Subsequently, the leaf samples were washed with deionized water dried using forced-air circulation at $65{ }^{\circ} \mathrm{C}$ for 72 $\mathrm{h}$ and ground. Then, the macronutrients were determined according the methods of Malavolta et al. (1997), and Korndörfer et al. (2004) for Si. The N was extracted using $\mathrm{H}_{2} \mathrm{SO}_{4}$, and the other nutrients were extracted using a nitro-perchloric solution. Both acid extraction were performed in a block digester. The $\mathrm{N}$ concentration was determined from the extracted solution using the Kjeldahl distillation method, and the $\mathrm{P}, \mathrm{K}, \mathrm{Ca}, \mathrm{Mg}$, and $\mathrm{S}$ concentrations were determined using atomic absorption spec- 
trophotometry. The Si concentration were determined by $0.1 \mathrm{~g}$ from the plant tissue were wet with $2 \mathrm{~mL}$ of $50 \% \mathrm{H}_{2} \mathrm{O}_{2}$ in polyethylene tubes. Next, $3 \mathrm{~mL}$ of $50 \%$ $\mathrm{NaOH}$ was added to each tube at room temperature. The tubes were placed in a double boiler for $1 \mathrm{~h}$ and in an autoclave at $138 \mathrm{kPa}$ for $1 \mathrm{~h}$. After atmospheric pressure was reached, the tubes were removed and 45 $\mathrm{mL}$ of water was added. The tubes were allowed to rest for $12 \mathrm{~h}$ before a $1-\mathrm{mL}$ aliquot of the supernatant solution was set aside and $15 \mathrm{~mL}$ of water, $1 \mathrm{~mL}$ of $\mathrm{HCl}$ $\left(500 \mathrm{~g} \mathrm{~L}^{-1}\right)$, and $2 \mathrm{~mL}$ of ammonium molybdate were added. After 5 to $10 \mathrm{~min}, 2 \mathrm{~mL}$ of oxalic acid $(500 \mathrm{~g}$ $\mathrm{L}^{-1}$ ) were added. The Si concentration was determined with a spectrophotometer at a wavelength of $410 \mathrm{~nm}$.

The soybean crops were harvested on April $3^{\text {rd }}, 2007$, and samples were collected to evaluate the yield components (plant population, number of pods per plant, number of grains per pod and the mass of 100 grains) and grain yields (13\% moisture content).

Maize (Zea mays L.) was sown on December 2 ${ }^{\text {nd }}, 2007$ using a row spacing of 0.45 mand a sowing rate of 3 seed $\mathrm{sm}^{-1}$. The intermediate maturation-cycle 2B570 hybrid was chosen for this study. In addition, the seeds were treated with fungicide (vitavax + thiram $-50+50$ $\mathrm{g}$ of the active ingredient every $100 \mathrm{~kg}$ of seeds), and the base fertilizer consisted of $300 \mathrm{~kg} \mathrm{ha}^{-1}$ of the 08 28-16 NPK formula and plus side dressing N (January $\left.10^{\text {th }}, 2008\right)$ of $90 \mathrm{~kg} \mathrm{ha}^{-1}$ of $\mathrm{N}$ as urea, accounting for the soil chemical analysis results and the recommendations for the maize crops (Raij et al 1997).The full flowering state of maize occurred 64 days after seedling emergence. At the full flowering stage, 10 plants were sampled per plot to evaluate the shoot dry matter production. Additionally, the central, third portion of the 30 leaves was sampled at the base of the ear (Raij et al., 1997) for analyzing the macronutrient (N, P, K, $\mathrm{Ca}, \mathrm{Mg}$, and $\mathrm{S}$ ) and $\mathrm{Si}$ concentrations according to the methods of Malavolta et al. (1997) and Korndörfer et al. (2004), respectively.
Maize harvest occurred on April 1 ${ }^{\text {st }}$, 2008, and sampling was carried out to evaluate the yield components (plant population, ears per plant, number of grains per ear and the mass of 100 grains) and the final yield (13\% moisture content).

Soil samples were taken 6 (April 2007), 12 (October 2007) and 18 months (April 2008) after applying the correction materials at depths of 0.00-0.05, 0.05-0.10, $0.10-0.20,0.20-0.40$ and $0.40-0.60 \mathrm{~m}$. Six simple samples were randomly collected from the useful area of each plot and between the rows of the previous crop to form a compound sample. Next, these samples were dried, sieved (2-mm sieves) and analyzed according to Raij et al. (2001). The soil chemical characteristics $(\mathrm{pH}$, organic matter, potential $\mathrm{H}+\mathrm{Al}, \mathrm{P}$, $\mathrm{K}, \mathrm{Ca}, \mathrm{Mg}$, exchangeable $\mathrm{Al}^{+3}$ and $\mathrm{Si}$ ). The soluble Si concentrations in the soil were determined using a $0.01 \mathrm{~mol} \mathrm{~L}^{-1} \mathrm{CaCl}_{2}$ solution and were quantified based on the formation of beta-molybdosilicic complexes using a spectrophotometer at $660 \mathrm{~nm}$, a described by Korndörfer et al. (2004). The efficiency use of fertilizer (EUF) applied on crops were calculated (3): EUF $\left(\mathrm{kg} \mathrm{kg}^{-1}\right)=$ Acumulated grain yield / Total Fertilizer applied

The data for all variables were analyzed by conducting an analysis of variance in the SISVAR statistical software package. The mean separations were conducted using the LSD test. The effects were considered as statistically significant at $p \leq 0.05$.

\section{Results}

The Figures 2, 3 and 4 shows the $\mathrm{pH}$, organic matter, $\mathrm{H}+\mathrm{Al}, \mathrm{Al}^{+3}$, and $\mathrm{Si}$ values after correcting soil acidity with lime and $\mathrm{Ca}-\mathrm{Mg}$ silicate. The addition of lime and $\mathrm{Ca}-\mathrm{Mg}$ silicate increased the soil $\mathrm{pH}$ at the depths 0.05 and $0.1 \mathrm{~m}$, respectively, 6 months after application. 
In addition, the soil correction as a function of silicate and lime application was also observed 12 months after the application of the treatments even in deeper layers, down to 0.4 and $0.2 \mathrm{~m}$, respectively. By the $18^{\text {th }}$ month, the effects of lime were not found in the deeper layers. However, the products from silicate dissociation had reacted throughout the entire profile.
The organic matter contents decreased at 0.05 and $0.1 \mathrm{~m}$ at 6 and 12 months after the application of lime and $\mathrm{Ca}-\mathrm{Mg}$ silicate, respectively. However, soil correction increased the organic matter contents at depths of 0.1-0.2 m after 18 months as a consequence of the treatments application (Figure 2).
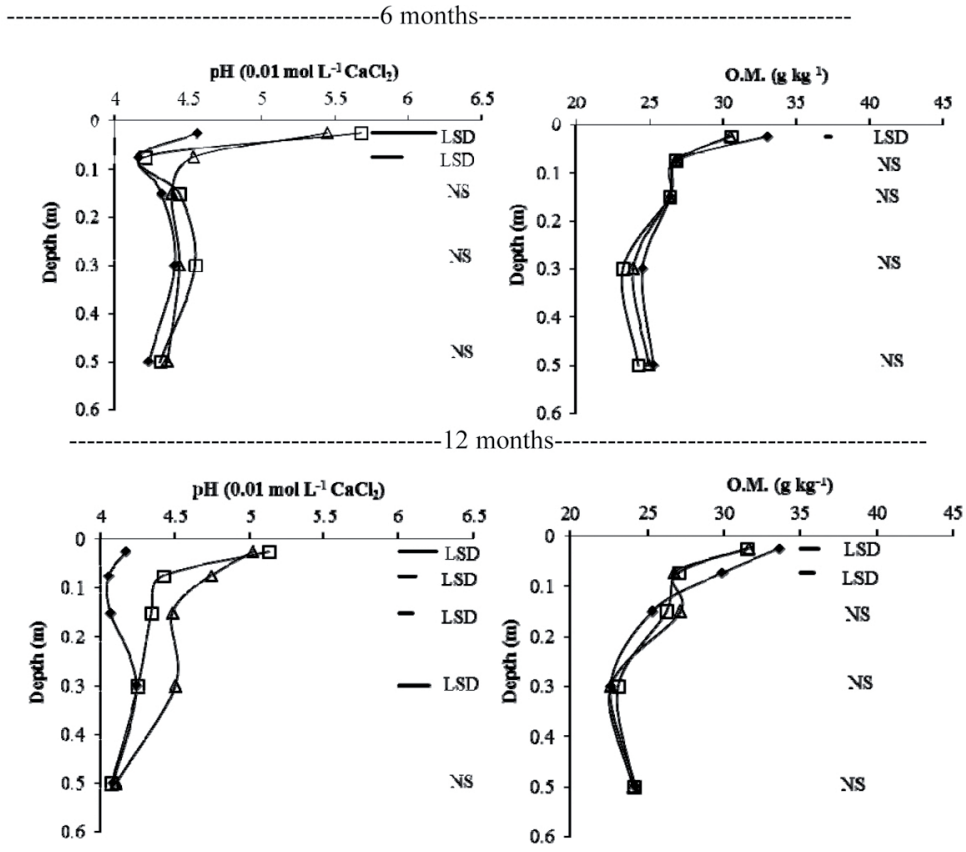

-18 months
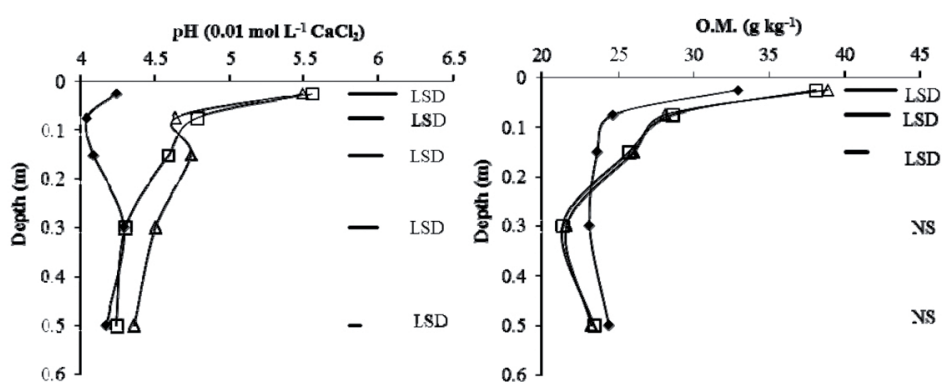

Figure 2. pH and organic matter (O.M.) level after 6, 12 and 18 months from the application of lime ( ), silicate ( ) and the control (f). Vertical bars indicate the least significant difference (LSD). 
Similarly, the potential acidity $(\mathrm{H}+\mathrm{Al})$ was neutralized down to $0.1 \mathrm{~m}$ after 6 months and $0.4 \mathrm{~m}$ after 12 months by both corrective sources. However, by the $18^{\text {th }}$ month, the Ca-Mg silicate reduced the acidity up to $0.4-0.6 \mathrm{~m}$ soil depth. In this final evaluation, liming effects were observed up to 0.1-0.2 $\mathrm{m}$ depth in comparison with the control (Figure 3).
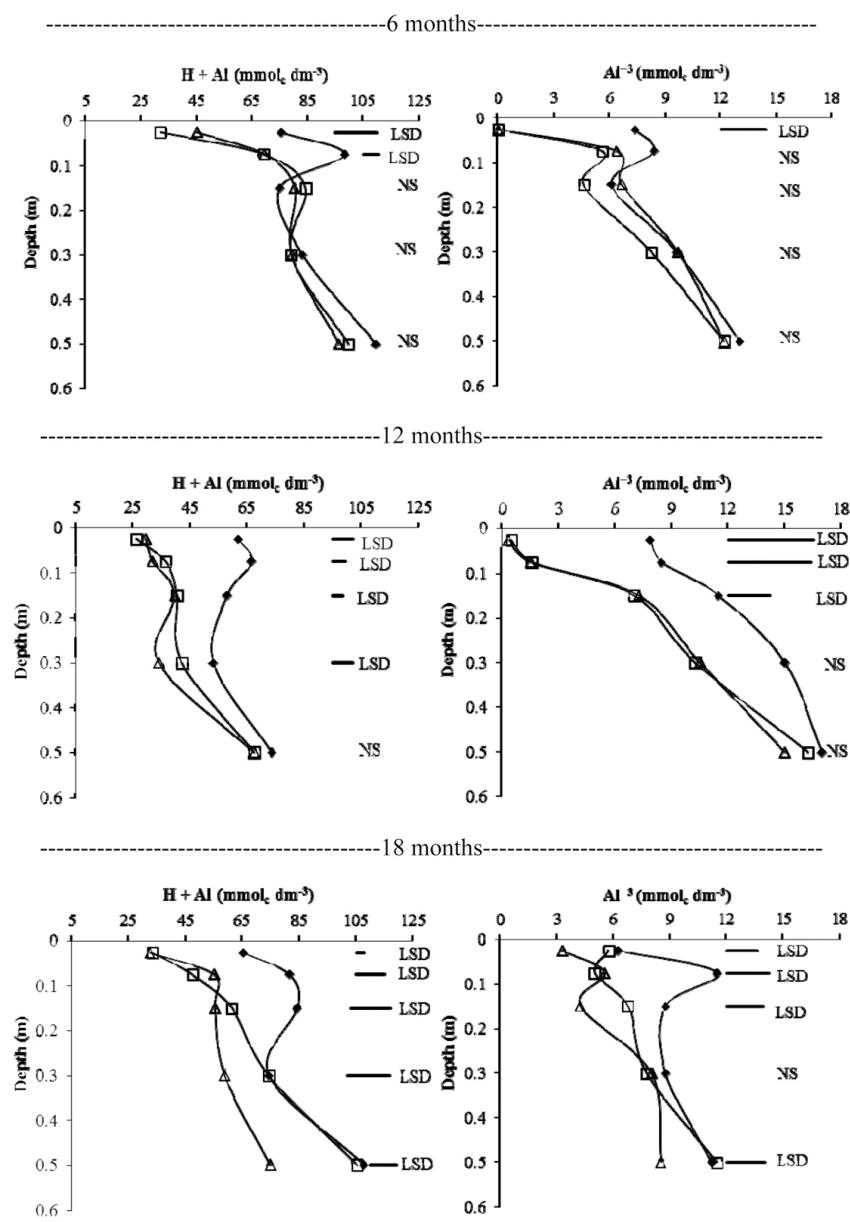

Figure 3. $\mathrm{H}+\mathrm{Al}$ andAl ${ }^{3+}$ levels after 6, 12 and 18 months from the application of lime ( ), silicate ( ) and the control (f). Vertical bars indicate the least significant difference (LSD).

Soil correction decreased the $\mathrm{Al}^{+3}$ concentrations until the depths of 0-0.05 and 0.1-0.2 $\mathrm{m}$ after 6 and 12 months, respectively. These effects were observed in the deepest soil layer 18 months following $\mathrm{Ca}-\mathrm{Mg}$ silicate application. The liming effects were confined to depths of 0.1-0.2 m (Figure 3).
For silicon, after 6 months of $\mathrm{Ca}-\mathrm{Mg}$ silicate application, there was an increase in soil concentrations to a depth of $0.20 \mathrm{~m}$. This effect was extended until $0.60 \mathrm{~m}$ after 12 and 18 months following $\mathrm{Ca}-\mathrm{Mg}$ silicate application. It is noteworthy that, liming after 12 months was also observed increase in Si concentrations, which 
were restricted to the soil depths of $0.05-0.10$ and $0.10-$ $0.20 \mathrm{~m}$ (Figure 4).

The Figures 4, 5 and 6 shows the $\mathrm{P}, \mathrm{K}^{+}, \mathrm{Ca}^{+2}$, and $\mathrm{Mg}^{+2}$ concentrations and the base saturation in the soil. Both materials for acidity correction efficiently improved the $P$ concentrations in the uppermost soil layer by the $6^{\text {th }}$ month after application. However, the P concentrations increased after the addition of silicate at depths of 0.05 $0.1 \mathrm{~m}$, which differed from the lime treatment and the control. Both sources increased the P concentrations at depths of 0-0.05 and 0.1-0.2 m. However, the effects of silicate were also observed from $0.05-0.1 \mathrm{~m}$ at 12 months after the application. After 18 months, silicate was more efficient than lime for increasing the P levels, which reached $0.1-0.2 \mathrm{~m}$.
The concentrations of $\mathrm{K}$ in the soil were not affected by the application of lime or silicate at 6 and 18 months after the application of the treatments (Figure 5). However, the $\mathrm{K}$ concentrations increased until $0.1 \mathrm{~m}$ depth as a consequence of the application of lime and silicate at 12 months after application.

Furthermore, the concentrations of $\mathrm{Ca}$ in the soil increased over time with the application of lime and silicate, even in the deepest soil layer (Figure 5). The addition of silicate resulted in greater $\mathrm{Ca}$ concentrations compared to lime and control treatments at depths of 0.10-0.20 and 0.20$0.40 \mathrm{~m}$ at 12 months after the application of the treatments, and at depths of $0.10-0.20$ and $0.40-0.60-\mathrm{m}$ at 18 months after the application of the treatments.
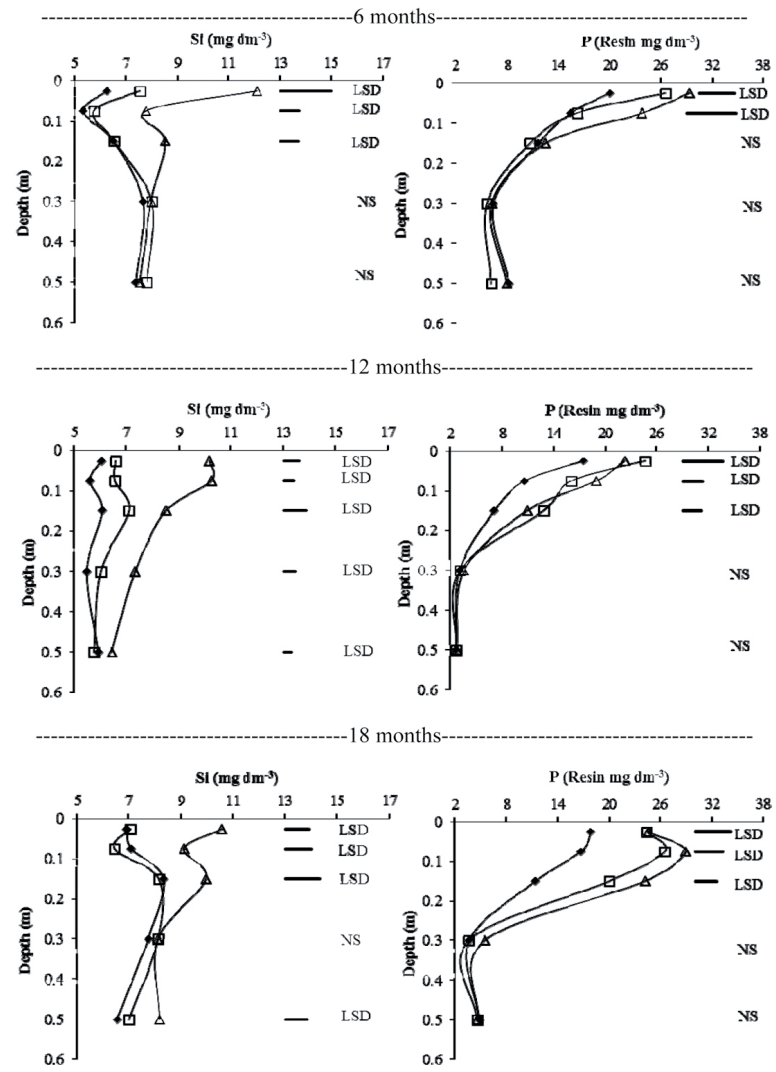

Figure 4. Si andP ${ }_{\text {resin }}$ levels after 6, 12 and 18 months from the application of lime ( ), silicate ( ) and the control (f). Vertical bars indicate the least significant difference (LSD). 


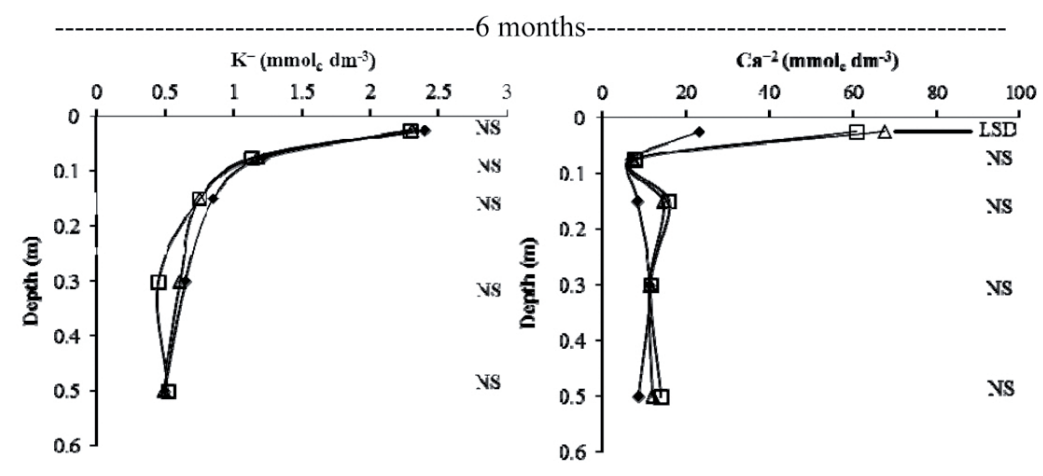

12 months

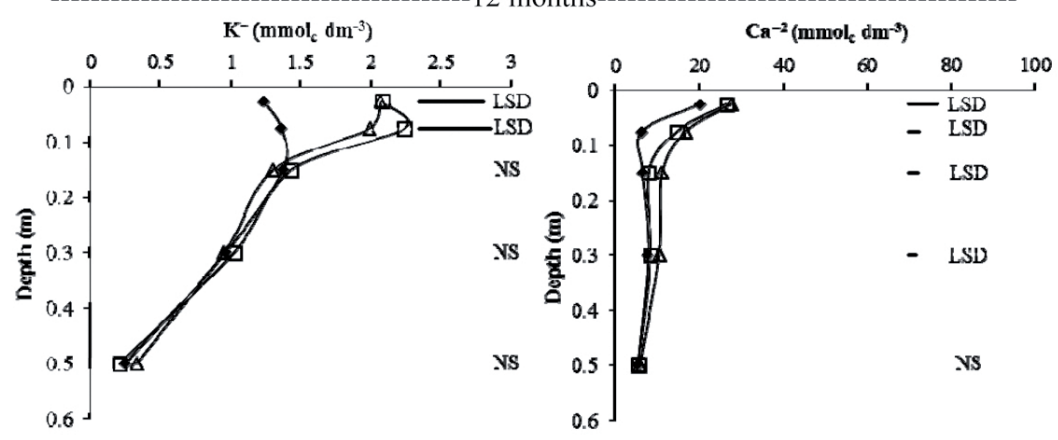

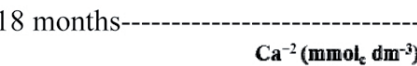

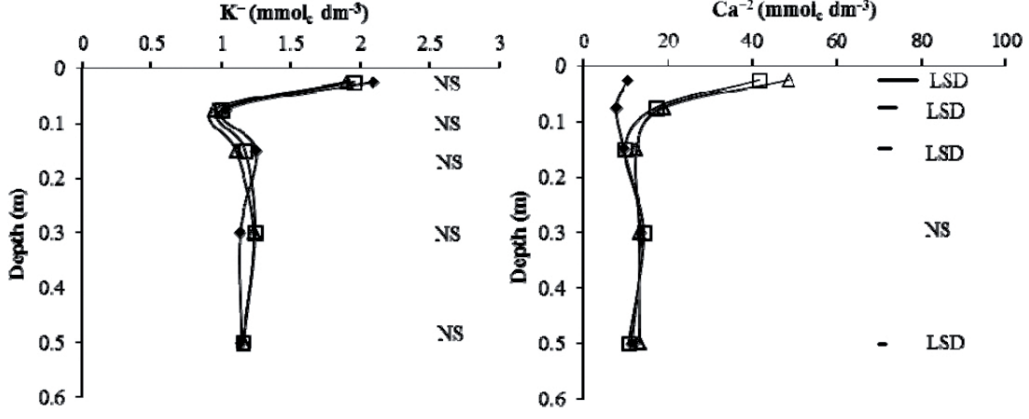

Figure 5. $\mathrm{K}^{+}$andCa ${ }^{2+}$ levels after 6, 12 and 18 months from the application of lime ( ), silicate ( ) and the control (f). Vertical bars indicate the least significant difference (LSD). 

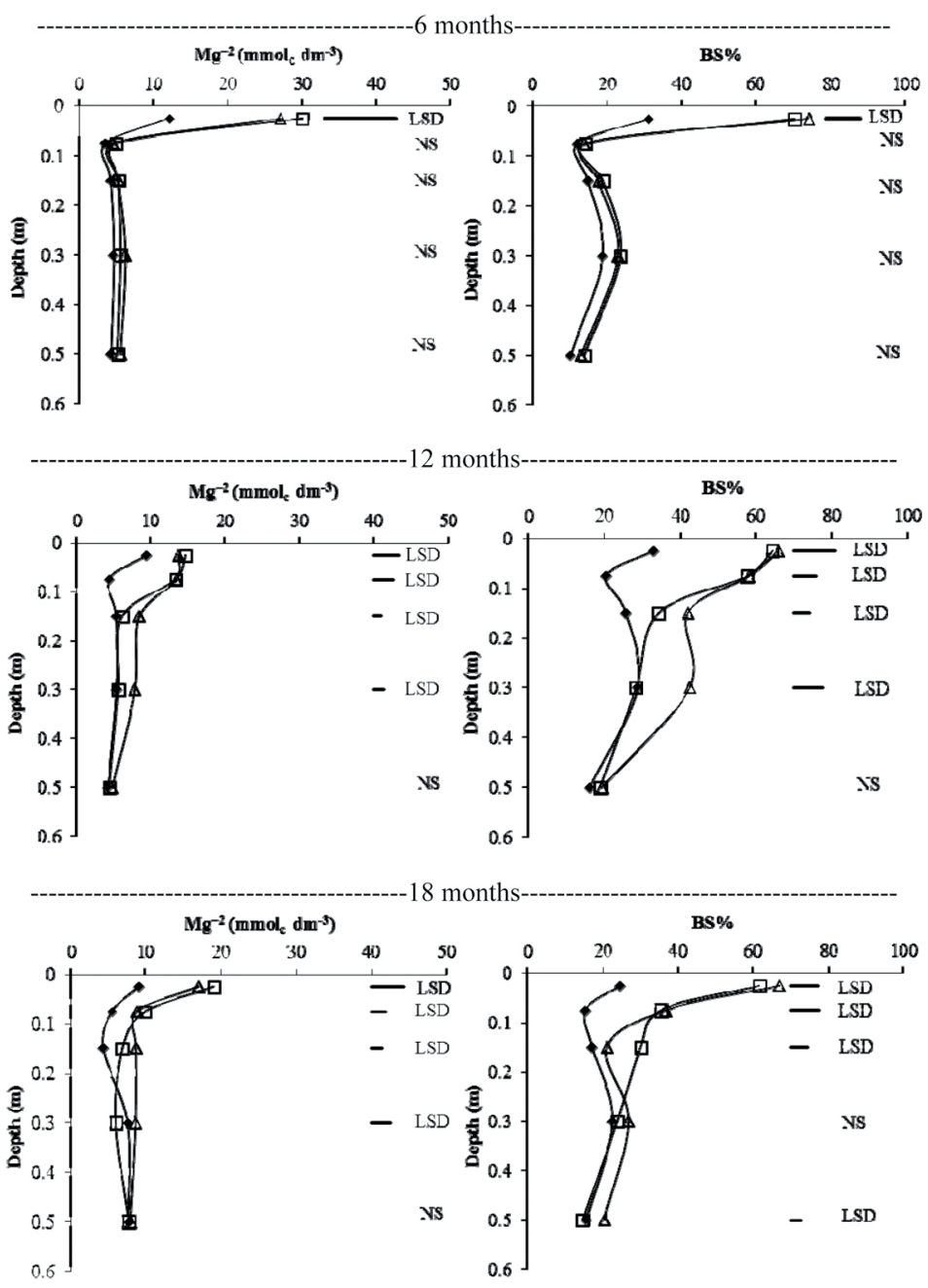

Figure 6. $\mathrm{Mg}^{2+}$ andBase Saturation (BS) levels after 6, 12 and 18 months from the application of lime ( ), silicate ( ) and the control (f). Vertical bars indicate the least significant difference (LSD) 
Efficiency use of Fertilizer Index

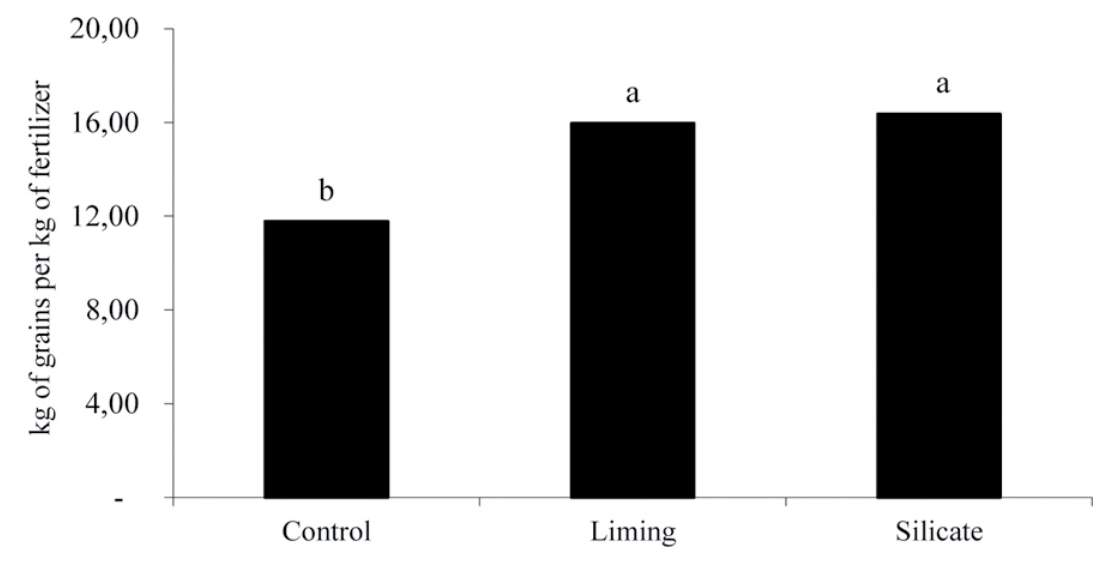

Figure 7. Efficiency use of fertilizers applied on soybean and maize affected by surface liming and silicate application under no tillage system. Columns followed by different letters differ statistically by the $t$ test $(p<0.05)$.

The effects of soil correction on the $\mathrm{H}+\mathrm{Al}, \mathrm{Ca}$ and $\mathrm{Mg}$ concentrations were reflected by the base saturation (Figure 6). Significant differences were found until the soil depths of $0.05,0.40$, and $0.60 \mathrm{~m}$ at 6 , 12 and 18 months after the treatments application, respectively. The main differences between the lime and silicate treatments were observed at depths of 0.20 $0.40 \mathrm{~m}$ and $0.40-0.60 \mathrm{~m}$ at 12 and 18 months after their application, respectively.

The concentrations of $\mathrm{N}, \mathrm{K}$, and $\mathrm{S}$ in the soybean leaves were not affected by the treatments at 6 months after the application (Table 1), but the application of lime and silicate increased the $\mathrm{Ca}$ and $\mathrm{Mg}$ concentra- tions in the leaves and silicate application $\mathrm{P}$ and $\mathrm{Si}$ concentrations in the leaves relative to the other treatments (Table 1).

The yield components and grain yields of soybean were affected by soil acidity correctives both treatments (Table 1). Both sources increased the shoot dry matter, although was higher after silicate application. Both sources increased the soybean dry matter production, plant population, number of pods per plant, number of grains per pod, the 100-grain weight and, consequently, the grain yield (Table 1). The application of lime and silicate increased the grain yield by 39.8 and $45.2 \%$, respectively. 
Table 1. Macronutrient (N, P, K, Ca, Mg, S and $\mathrm{Si}$ ) concentrations, dry matter production, yield components (plant population, number of pods per plant, number of grains per pod and 100 grain weight) and soybean yield affected by surface liming and silicate application under no tillage system. Botucatu, State of São Paulo, Brazil, 2006-2008.

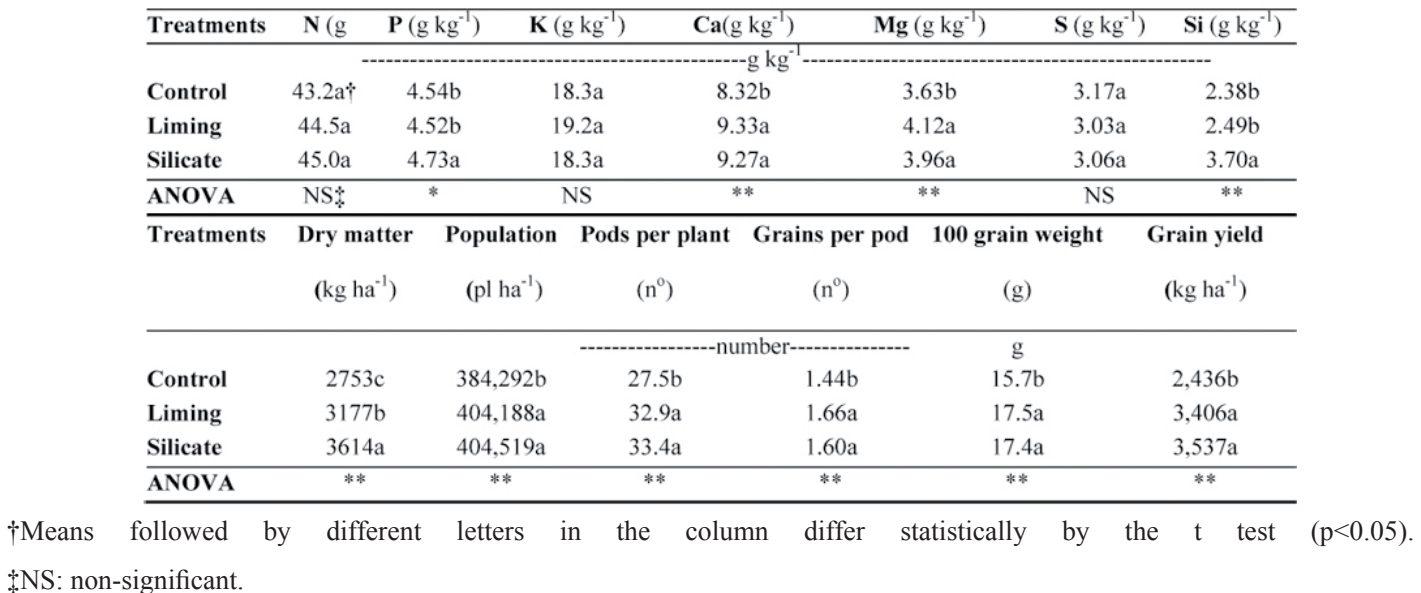

The treatments did not influence the $\mathrm{N}, \mathrm{P}, \mathrm{K}$, and $\mathrm{S}$ concentrations in the maize leaves (Table 2). However, the $\mathrm{Ca}$ and $\mathrm{Mg}$ concentrations increased following the application of lime and silicate. This trend was also observed for soybean. The application of soil acidity correctives increased the Si concentrations in the plant leaves, especially with the silicate application.

Among the yield components of maize, the treatments did not influence the ear index and 100-grain mass (Table 2). In contrast, as a consequence of the lime and silicate application the shoot dry matter production, plant population, and the number of grains per ear increased, which was directly reflected by the yield increases of 33.5 and $36 \%$ after lime and silicate application, respectively. The fertilizer use efficiency also increased from $11.7 \mathrm{~kg}$ of grains per kilogram of fertilizer applied (control) to 16.0 and $16.4 \mathrm{~kg}$ after the application of lime and silicate, respectively (Figure 7). 
Table 2. Macronutrient (N, P, K, Ca, Mg, S and $\mathrm{Si}$ ) concentrations, dry matter production, yield components (plant population, ear index, number of grains per ear and 100 grain weight) and maize yield affected by surface liming and silicate application under no tillage system. Botucatu, State of São Paulo, Brazil, 2006-2008.

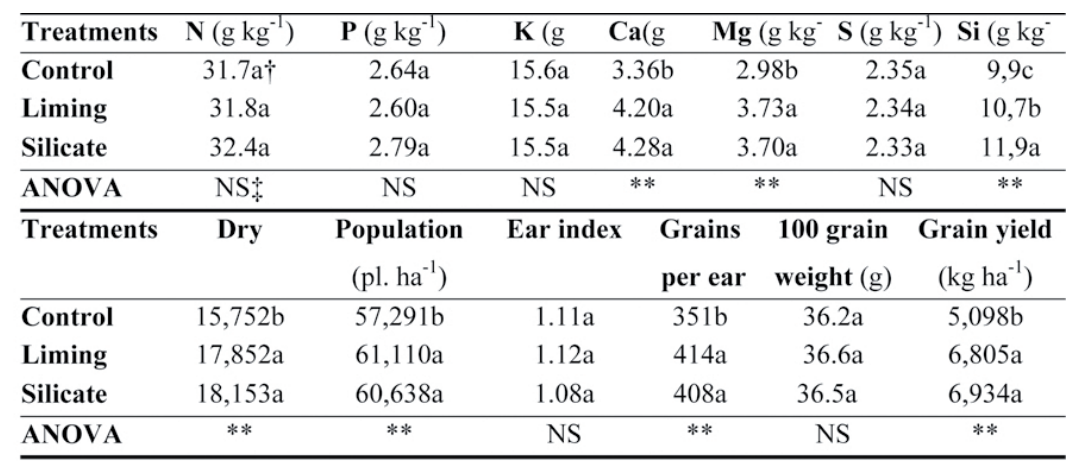

$\dagger$ Means followed by different letters in the column differ statistically by the $\mathrm{t}$ test $(p<0.05)$.

$\$ N S$ : non-significant.

\section{Discussion}

The lime and silicate application increased the soil $\mathrm{pH}$, which reduced the $\mathrm{H}+\mathrm{Al}$ levels (Figures 2 and 3). The silicate effects on $\mathrm{pH}$ and $\mathrm{H}+\mathrm{Al}$ were observed throughout the soil profile after 18 months, while the effects of lime were limited to the superficial layers. Corrêa et al. (2007) compared the effects of surface liming $\left(2.000 \mathrm{~kg} \mathrm{ha}^{-1} ; \mathrm{ECC}=71 \%\right)$ with three rates of Ca-Mg silicate as slag $\left(2.000,4.000\right.$ and $8.000 \mathrm{~kg} \mathrm{ha}^{-1}$; $\mathrm{ECC}=48 \%$ ). These authors found that silicate were more efficient to correct soil acidity because all the slag rates increased the soil $\mathrm{pH}$ up to $0.40 \mathrm{~m} 15$ months after the application. In contrast, the superficial limingonly corrected the soil $\mathrm{pH}$ up to $0.10 \mathrm{~m} 15$ months after the application. Costa and Crusciol (2016) in a long term study verified that the $\mathrm{pH}$ values increased until 0,20 m in a Rhodic Hapludox at 48 months after the surface reapplication of lime.

The hydroxyl concentration increased and the $\mathrm{H}^{+}$concentration decreased in the soil solution as a function of the application of the sources of soil acidity correction, which increased the soil $\mathrm{pH}$ (Oliveira and Pavan, 1996).

Many no tillage system studies have demonstrated the effects of surface liming on correcting the subsurface soil layers (Caires et al., 2011; Correa et al., 2007; Soratto and Crusciol, 2008; Costa and Crusciol, 2016).

Soratto and Crusciol (2008) observed that surface liming decreased the $\mathrm{H}+\mathrm{Al}$ concentrations at depths of 0.05-0.1 $\mathrm{m}$ and 0.1-0.2 $\mathrm{m}$ at 6 and 12 months after surface liming, respectively. This effect was dependent on the product dose and particle size, and on the application method, soil, climate factors (especially rainfall), tillage system and time of application (Oliveira and Pavan, 1996; Soratto and Crusciol, 2008). All of the cited factors affected this management efficiency, particularly when applied for subsurface correction of the soil acidity. Additionally, correctives sources appear to have distinct solubility 
properties and dissociation rates that affect their ion mobility throughout the profile.

One hypothesis that explains why silicate is more efficient in correcting acidity throughout the soil profile is its higher solubility when compared to lime (Alcarde and Rodella, 2003). Because silicate reacts faster in the uppermost soil layers, and analkalinization front occurs which corrects the acidity of deeper layers over a shorter period.

The organic matter content decreased due to lime and silicate at 6 and 12 months after the application (Figure 2), potentially due to the higher microbial activity that resulted from the higher $\mathrm{pH}$ values (Fuentes et al., 2006), and can promote accelerated soil organic matter (SOM) decomposition (Yao et $a l ., 2009$ ) and can lead to significant loss of C, especially in the light fraction C (Briedis et al., 2012). However, after medium-term (18 months), this effect was reduced due to the greater biomass productivity per area, shoots (Table 1 and 2) and roots by liming (Ridley et al., 1990; Hati et al., 2008), and occurred as a consequence of improvements in soil fertility attributes such as $\mathrm{pH}$, the $\mathrm{Ca}$ and $\mathrm{Mg}$ supply, and reductions of $\mathrm{Al}^{3+}$ concentration (Figure 2, 3, 5 and 6). When comparing the $\mathrm{Al}^{+3}$ with $\mathrm{Si}$ concentrations in the soil, the Si concentrations were greater at depths where the concentrations of toxic $\mathrm{Al}^{+3}$ were reduced (Figures 3 and 4). Thus, in addition to the effects of increasing soil $\mathrm{pH}$ and organic matter (Álvarez et al., 2012), the $\mathrm{Al}^{+3}$ content may be reduced due to its reaction with and later precipitation as hydroxoalumino silicate (HAS) (Exley, 1998) and Al organic complexation (Álvarez et al., 2012).

The Si concentrations in the soil increased at 12 and 18 months after the application of lime at depths of 0.05-0.10 m, similarly to Pulz et al. (2008). In addition, the application of silicate resulted in greater Si concentrations at all soil depths 12 months after the application (Figure 4), which emphasized the efficiency of silicate for supplying $\mathrm{Si}$.

Both sources of acidity correction efficiently improved the $\mathrm{P}$ concentrations in the uppermost soil layer (Figure 4). This result occurred due to the interactions of several factors that increased the hydroxyl concentrations and ionic activities in the soil solution (Monfort et al., 2015), including the $\mathrm{pH}$ and the precipitation of $\mathrm{Fe}$ and $\mathrm{Al}$.

In contrast, the precipitation of $\mathrm{P}-\mathrm{Fe}$ and $\mathrm{P}-\mathrm{Al}$ minerals with low solubility decreased. Additionally, negative charges are generated by $\mathrm{OH}^{-}$deprotonation and exposed by clays and organic matter. Consequently, phosphate is repelled by the adsorption surface (Mcbride, 1994), which releases $P$ into the soil solution. Thus, it was expected that both materials for the acidity correction would increase the availability of $\mathrm{P}$.

Nevertheless, the benefits of silicate applications increased due to the competition between $\mathrm{Si}$ and $\mathrm{P}$ for the same soil colloid sorption sites, which increased the P availability to the plants (Pulz et al., 2008). These sites are saturated or blocked by the silicate anion, which improved the efficiency of P fertilization. The potassium concentrations in the soil were only influenced by the lime and silicate application in the superficial layers $(0-0.10 \mathrm{~m})$ at 12 months after the application (Figure 5). Flora et al. (2007) reported better $\mathrm{K}$ availability in the soil after liming due to reduced leaching. Soil correction increased the $\mathrm{pH}$ and the amount of negative charges in the uppermost soil layers (Albuquerque et al., 2003) where $\mathrm{K}^{+}$ions were adsorbed. The acidity correction sources decreased the $\mathrm{K}^{+}$mobility with soil depth.

According to Flora et al. (2007), the amount of negative charges increased and retained K. Furthermore, the addition of $\mathrm{K}$ may be related to ion leaching from plant tissues (Rosolem et al., 2007) because as a consequence of the application of both sources of soil acidity correction greater dry matter production 
was observed in comparison to the control treatment (Tables 1 and 2).

The $\mathrm{Ca}$ and $\mathrm{Mg}$ concentrations were influenced by soil correction similarly (Figures 5 and 6). The effects of silicate were observed at depths of 0.00-0.05 and $0.20-0.40 \mathrm{~m}$ at6 and $12 \mathrm{months}$ after the application, respectively.

The lime application provided 10\% more $\mathrm{Mg}$ than silicate, but both sources affected the $\mathrm{Mg}$ concentrations in the uppermost soil layer similarly 12 and 18 months after their application. Nevertheless, their effects were different from 0.10 to $0.40 \mathrm{~m}$ depth. Specifically, higher $\mathrm{Mg}$ concentrations were observed as a consequence of silicate application in comparison to lime (similar results were observed by Corrêa et al., 2007) and may be explained by the higher silicate solubility which can intensify the leaching of $\mathrm{Mg}$ to deeper depths.

The mobility of basic cations in tropical soils $\left(\mathrm{K}^{+}\right.$, $\mathrm{Ca}^{2+}$, and $\mathrm{Mg}^{2+}$ ) is hindered by their adsorption to variable negative charges as the $\mathrm{pH}$ increases (Caires et al., 2006). Therefore, mobility may have been favored by the formation of ionic pairs between cations and inorganic compounds. These compounds potentially originated from the dissociation of correction sources of soil acidity or anions released through root exudation in the rhizosphere, such as $\mathrm{OH}^{-}$and $\mathrm{HCO}_{3}^{-}$, as well as nitrate $\left(\mathrm{NO}_{3}^{-}\right)$, sulphate $\left(\mathrm{SO}_{4}{ }^{2-}\right)$, and chloride $\left(\mathrm{Cl}^{-}\right)$from fertilizer mineralization or residue decomposition at the soil surface (Crusciol et al., 2011). In addition, organic ionic pairs formed by soil cations and water-soluble compounds with low molecular weight (originated from residue decomposition through $\mathrm{C}=\mathrm{O}-\mathrm{OH}$ radicals) may improve ion mobility throughout the profile (Castro et al., 2012).

The variations in the $\mathrm{pH}$ and base saturation and the cation mobility through the soil profile depend on the absence of acid cations in the surface soil layers, which are preferentially bound. According to Fageria and Baligar (2008), this result can be observed at $\mathrm{pH}$ $\left(\mathrm{H}_{2} \mathrm{O}\right)$ values between 5.2 and 5.5.

Regarding the soil macronutrient concentrations (Tables 1 and 2), all of the concentrations were within the range that was considered appropriate for soybean and maize with the exception of the K levels for soybeans (Raij et al., 1997). The different treatments did not influence the $\mathrm{N}, \mathrm{K}$, and $\mathrm{S}$ concentrations, likely because they did not have enough time to increase the microbial activity and improve the organic matter mineralization (Fuentes et al., 2006).

The increases in $\mathrm{Ca}$ and $\mathrm{Mg}$ in the plants due to the superficial application of correctives of soil acidity (Tables 1 and 2) have also been observed by other authors (Mali and Aery, 2008; Costa and Crusciol, 2016). These effects have been attributed to the increases in the exchangeable $\mathrm{Ca}$ and $\mathrm{Mg}$ in the soil profile (Figure 5 and 6) that allows the plant roots explore a large volume of soil.

The application of silicate resulted in greater $\mathrm{P}$ in the soybean leaves (Table 1). In contrast, increasing the $\mathrm{P}$ concentrations in the leaves by the addition of silicate in the soil is related to the competition of silicate $\left(\mathrm{H}_{3} \mathrm{SiO}_{4}^{-}\right)$and phosphate $\left(\mathrm{H}_{2} \mathrm{PO}_{4}^{-}\right)$for the same sorption sites (Figure 3) (Plucknett, 1972). Pulz et al. (2008) also observed higher P availability in soils and in the leaves of potato plants after the application of silicate in comparison to lime.

The correction of soil acidity with silicate increased Si concentration in soybean and maize leaves, and in maize higher values were found after lime application compared to the control (Tables 1 and 2). The silicate is a source of $\mathrm{Si}$ that increases their availability in the soil (Figure 2). The increased Si concentrations in the soil by liming was also observed by Ramos et al. (2006), and they explained that $\mathrm{pH}$ is extremely important to Si availability for plants.

The yield components and grain yields of soybean and maize were greater following the application 
of lime and silicate (Tables 1 and 2). Corrêa et al. (2008) studied surface liming and the application of silicate as slag and observed that both treatments increased the yield components individually, which increased the soybean yield. Miranda et al. (2005) also observed similar results for maize with the superficial application of the correction sources of soil acidity. In fact, the maize yield is correlated to soil pH (Nájera et al., 2015).

Nevertheless, research conducted in Southern Brazil has shown that soybeans do not respond significantly to surface liming in no-till systems. According to Caires and Fonseca (2000), organic matter conservation and moisture contents in topsoil layers improve in no tillage systems, which favor nutrient uptake by plants even in acid soils. Consequently, the beneficial effects of liming may be minimized under appropriate rainfall conditions.

The response to soil acidity correction is potentially greater in locations with lower amounts of crop residues at the soil surface. For example, this situation occurs in dry-winter regions in Brazil, such as the Cerrado biome, where most areas are only cropped once each year. Significant results have been observed in soils with low exchangeable $\mathrm{Mg}$ concentrations for all cropping systems (Oliveria and Pavan, 1996).

The soil acidity correction increased efficiency of fertilization (Figure 7). According to Crusciol and Soratto (2010), fertilizer efficiency depends on soil management practices, such as tillage system, crop rotation, crop succession, green manure application, and the application of conservation practices. The efficient use of fertilizers and correction sources has become increasingly relevant to Brazilian agriculture due to increased input prices, higher crop yields, higher production, and the risk of environmental contamination due to inappropriate input use. Thus, it is important to study all factors that influence fertilizer efficiency and to identify the best management practices for maximizing fertilizer efficiency.

\section{Conclusions}

Considering the results of this experiment, the hypothesis that silicate is an efficient source for acidity correction is valid because it increases the number of exchangeable bases in the soil equivalent than lime. Additionally, silicate increases the availability of Si for plants and phosphorus concentrations in the soybean shoots due to the greater phosphorus concentrations in the soil. Nevertheless, the application of both lime and silicate increased the calcium and magnesium concentrations, the yields components, and the yields of soybean and maize. Consequently, both sources of soil acidity correction improved the efficiency of fertilizer use when applied for grain production.

\section{Acknowledgements}

To the São Paulo Research Foundation (FAPESP) for financial support (Registry number: 2006/01705-4), and to the National Council for Scientific and Technological Development (CNPq) for an award for excellence in research of the second author.

\section{References}

Alcarde, J.A., Rodella, A.A. 2003. Qualidade e legislação de fertilizantes e corretivos, in Curi, N., Marques, J.J., Guilherme, L.R.G., Lima, J.M. de, Lopes, A. S., Alvarez, V.: Tópicos em Ciência do Solo. Sociedade Brasileira de Ciência do solo, Viçosa, Brazil, 291-334.

Álvarez, E., Fernández-Sanjurjo, M.J., Núñez, A., Seco, N., Corti, G. 2012. Aluminium fractionation and speciation in bulk and rhizosphere of a grass soil amended with mussel shells or lime. Geoderma. 173-174, 322-329. 
Caires, E.F., Fonseca, A.F. 2000. Absorção de nutrientes pela soja cultivada no sistema de plantio direto em função de calagem na superfície. Bragantia. $59,213-220$.

Caires, E.F., Garbuio, F.J., Alleoni, L.R.F., Cambri, M.A. 2006. Aplicação de corretivos superficial e cobertura de aveia preta antecedendo os cultivos de milho e soja em sistema plantio direto. Rev. Bras. Cienc. Solo. 30, 87-98.

Caires, E.F., Joris, H.A.W., Churka, S. 2011. Longterm effects of lime and gypsum additions on no-till corn and soybean yield and soil chemical properties in southern Brazil. Soil Use and Management. 27, 45-53.

Castro, G.S.A., Calonego, J.C., Crusciol, C.A.C. 2011. Soil physical properties in crop rotation systems as affected by liming materials. Pesqui. Agropecu. Bras. 46, 1690-1698.

Castro, G.S.A., Crusciol, C.A.C., Menegale, M.L. C.2012. Calagem e silicatagem superficiais e a disponibilidade de cátions hidrossolúveis em culturas anuais e braquiária. Rev. Cienc. Agron. 43, 740-748.

Corrêa, J.C., Büll, L.T., Crusciol, C.A.C., Marcelino, R. 2007. Correção da acidez e mobilidade de íons em Latossolo com aplicação superficial de escória, lama cal, lodos de esgoto e calcário. Pesqui. Agropecu. Bras. 42, 1307-1317.

Costa, C.H.M., Crusciol, C.A.C. 2016. Long-term effects of lime and phosphogypsum application on tropical no-till soybean-oat-sorghum rotation and soil chemical properties. Europ. J. Agronomy. 74, 119-132.

Crusciol, C.A.C., Soratto, R.P. 2010. Sistemas de produção e eficiência agronômica de fertilizantes. In: Prochnow, L.I., Casarin, V., Stipp, S.R. Boas práticas para uso eficiente de fertilizantes: contexto mundial e técnicas de suporte, IPNI, Piracicaba, Brazil, pp. 229-275.
Crusciol, C.A.C., Garcia, R.A., Castro, G.S.A., Rosolem, C.A. 2011. Nitrate role in basic cation leaching under no-till. Rev. Bras. Ciênc. Solo. 35, 1975-1984.

Crusciol, C.A.C., Artigiani, A.C.C.A., Arf, O., Carmeis Filho, A.C.A., Soratto, R.P., Nascente, A.S., Alvarez, R.C.F. 2016. Soil fertility, plant nutrition, and grain yield of upland rice affected by surface application of lime, silicate, and phosphogypsum in a tropical no-till system. Catena. 137, 87-99.

Dorneles, A.O.S., Pereira, A.S., Rossato, L.V., Possebom, G., Sasso, V.M., Bernardy, K., Sandry, R.Q., Nicoloso, F.T., Ferreira, P.A.A., Tabaldi, L.A. 2016. Silicon reduces aluminum content in tissues and ameliorates its toxic effects on potato plant growth. Ciênc. Rural. 46, 506-512.

Exley, C. 1998. Silicon in life: a bioinorganic solution to bioorganic essentiality. J. Inorg. Biochem., 69, 139-144.

Fageria, N.K., Baligar, V.C. 2008. Ameliorating soil acidity of tropical oxisols by liming for sustainable crop production. Adv. Agron. 99, 345-399.

Flora, L.P.D., Ernani, P.R., Cassol, P.C. 2007. Mobilidade de cátions e correção da acidez de um Cambissolo em função da aplicação superficial de calcário combinado com sais de potássio. Rev. Bras. Cienc. Solo. 31, 1591-1598.

Fuentes, M., González-Gaitano, G., García-Mina, J. M. 2006. The usefulness of UV-visible and fluorescence sepectroscopies to study the chemical nature of humic substances from soils and composts. Org. Geochem. 37, 1949-1959.

Gallardo, F., Briceño, G., Flores, M.J., Diez, M.C. 2016. Recycling pulp mill sludge to volcanic soil: a column leaching study. Soil Sci. Plant Nutr. 16, 248-261.

Navarro, F.J.G., Amorósortiz-Villajos, J.A., Sánchez Jiménez, C.J., Martín-Consuegra, S.B., Cubero, E.M., Ballesta, R.J. 2009. Application of sugar foam to red soils in a semiarid Mediterranean environment. Environ. Earth Sci. 59, 603-611. 
Haynes, R.J. 2014. A contemporary overview of silicon availability in agricultural soils. J. Plant Nutr. Soil Sci. 1-14.

Korndörfer, G.H., Pereira, H.S., Nolla, A. 2004. Análise de silício: solo, planta e fertilizante. GPSi-ICIAG-UFU, Boletim Técnico No. 2, Uberlândia.

Ma, J.F., Yamaji, N. 2006. Silicon uptake and accumulation in higher plants. Trends in PlantSci. 11, 392-397.

Malavolta, E., Vitti, G.C., Oliveira, A.S. 1997. Avaliação do estado nutricional de plantas: princípios e aplicações. Potafós Publishing, Piracicaba, Brazil.

Mali, M., Aery, N.C. 2008. Silicon effects on nodule growth, dry-matter production, and mineral nutrition of cowpea (Vigna unguiculata). J. Plant Nutr. Soil Sci, 171, 835-840.

McBride, M.B. 1994. Environmental chemistry of soils. Oxford University Press, New York.

Miranda, L.N., Miranda, J.C.C., Rein, T.A., Gomes, A.C. 2005. Utilização de calcário em plantio direto e convencional de soja e milho em Latossolo Vermelho. Pesqui. Agropecu. Bras. 40, 563-572.

Monfort-Salvador, I., García-Montero, L.G., Grande, M.A. 2015. Impact of calcium associated to calcareous amendments on ectomycorrhizae in forests: a review. J. Soil Sci. Plant Nutr. 15, 217-231.

Nájera, F., Tapia, Y., Baginsky, C., Figueroa, V., Cabeza, R., Salazar, O. 2015. Evaluation of soil fertility and fertilization practices for irrigated maize (Zea mays L.) under Mediterranean conditions in Central Chile. J. Soil Sci. Plant Nutr. 15, 84-97.
Oliveira, E.L., Pavan, M.A. 1996. Control of soil acidity in no-tillage system for soybean production. Soil and Tillage Res. 38, 47-57.

Plucknett, D.L. 1972. The use of soluble silicates in Hawaii agriculture. University of Queensland Papers 1, 203-223.

Prabagar, S., Hodson, M.J., Evans, D.E. 2011. amelioration of aluminium toxicity and cell death in suspension cultures of Norway spruce (Piceaabies (L.) Karst.). Environ. Exp. Bot. 70, 266-276.

Pulz, A.L., Crusciol, C.A.C., Lemos, L.B., Soratto, R.P. 2008. Influência de silicato e calcário na nutrição, produtividade e qualidade de batata sob deficiência hídrica. Rev. Bras. Cienc. Solo. 32, 1651-1659.

Raij, B.V., Andrade, J.C., Cantarella, H., Quaggio, J.A. 2001. Análise química para avaliação da fertilidade de solos tropicais. Instituto Agronômico de Campinas (IAC), Campinas, Brazil.

Raij, B.V., Cantarella, H., Quaggio, J.A., Furlani, A.M.C. 1997. Recomendações de adubação e calagem para o Estado de São Paulo. Instituto Agronômico de Campinas (IAC), Campinas, Brazil.

Ramos, L.A., Nolla, A., Korndörfer, G.H., Pereira, H.S., Camargo, M.S.de. 2006. Reatividade de corretivos da acidez e condicionadores de solo em colunas de lixiviação. Ver. Bras. Cienc. Solo. 30, 849-857.

Soratto, R.P., Crusciol, C.A.C. 2008. Dolomite and phosphogypsum surface application effects on annual crops nutrition and yield. Agron. J. 100, 261-270. 